\title{
The Effect of Cajanus Cajan Seeds Extraction on Some Haematological Parameters Among Haemorrhagical Anaemic Rats in Khartoum-Sudan
}

\author{
Khalid Mohamed Khalid Elhussain ${ }^{1-3 *}$, Nora Nahal Bouderba ${ }^{4}$, Salma HaiderMohmmed Abu Algasim ${ }^{1}$, \\ TasbihElhadi Mohammed Ahmed ${ }^{1}$, Weam Mustafa Hasab Alrasol ${ }^{1}$, Wegdan Ibrahim Ahmmed ${ }^{1}$, \\ Mohammed ElfatihHussein Ournasseir ${ }^{1,2}$ and Abdulazeem Abdulsalam Ibrahim Alkhidir ${ }^{1,2}$ \\ ${ }^{1}$ Omdurman Islamic University, Faculty of Medical laboratory sciences, sudan \\ ${ }^{2}$ Omdurman Ahlia University, Faulty of Medicine, Sudan \\ ${ }^{3}$ International University of Africa, Faculty of Medical laboratory sciences, Sudan \\ ${ }^{4}$ Biology department, Faculty of Science of Nature and Life, Algeria \\ *Corresponding author: Khalid Mohamed Khalid Elhussain, Omdurman Islamic University, Faculty of Medical laboratory sciences, \\ Sudan, Tel: 00249912275275, Email: klebs88@gmail.com
}

\section{ARTICLE INFO}

Received: 幽 February 03, 2020

Published: 慧 February 12, 2020

Citation: Khalid Mohamed Khalid Elhussain, Nora Nahal Bouderba, Salma HaiderMohmmed Abu Algasim, TasbihElhadi Mohammed Ahmed, Weam Mustafa Hasab Alrasol, Wegdan Ibrahim Ahmmed, Mohammed Elfatih Hussein Ournasseir, Abdulazeem Abdulsalam Ibrahim Alkhidir. The Effect of Cajanus Cajan Seeds Extraction on Some Haematological Parameters Among Haemorrhagical Anaemic Rats in Khartoum-Sudan. Biomed J Sci \& Tech Res 25(4)-2020. BJSTR. MS.ID.004220.

Abbreviations: MAPRI: Medicinal and Aromatic Plants Research Institute; NCR: National Centre for Research; CSA: Cajaninstilbene Acid; NO: Nitric Oxide; LPS: Lipopolysaccharides; HFD: High-Fat Diet; TC: Total Cholesterol; TG: Total Triglyceride; CPT-1: Carnitine Palmitoyltransferase-1

\section{ABSTRACT}

Background: Worldwide different plants were studied for their role in the treatment and correction of different types of anaemia's. The Medicinal and Aromatic Plants Research Institute (MAPRI) of the National Centre for Research (NCR) plays major role in medicinal and aromatic plants investigation, determination of therapeutic properties and documented in Sudan.

Objectives: This study used to determine the effect of Cajanus Cajan seeds extract on the some haematological parameters among hemorrhagic anaemia rats, Khartoum -Sudan.

Methods: Experimental randomised controlled trial study conducted among 24 healthy Wistar albino rats with both sex, ages (6weeks) and weighing between (75$130 \mathrm{~g}$ ), they were feed with standard laboratory chow. they divided into four groups each one consists of six rats.

Result: Dose group $(800 \mathrm{mg} / \mathrm{kg} /$ day $)$ represent highly significant increases in haemoglobin in W0\&W1 $P$ value $<0.001$, and W0\&W3 p value is 0.0002 .while the dose of $400 \mathrm{mg} / \mathrm{kg} /$ day significant increase in W0\&W1 p value is $<0.003$ and W0\&W3 $p<0.00004$, in the dose of $200 \mathrm{mg} / \mathrm{kg} /$ day represent also significant increase at W0\&W1 $\mathrm{p}<0.005$ and in W0\&W3p<0.007 respectively, when compared to control values(Group1).

Conclusion: This study revealed that there are increased in some haematological parameters and lend support to the use of ethanol seeds extract of Cajanus Cajan in treatment of hemorrhagic anaemia.

Keywords: Aromatic Plants; Cajanus Cajan; Wistar Albino Rats; Hemorrhagic Anaemia

\section{Introduction}

Anemia is a condition in which there is a reduction in the number of circulating red blood cell, the amount of haemoglobin, or the volume of packed red cells and causes a reduction in the capacity of the blood to deliver oxygen to body tissues and organs [1]. Worldwide different plants were investigated for their role in the treatment and correction of different types of anemias, so 
herbal medications can be considered as one of the solutions to dietary of iron deficit and can be the replacement for food supplementation programs. Sudan with its vast areas is rich in wild plants that play an important role in the nutrition of different populations especially in rural areas, with multi- culture, habits rich biodiversity and medicinal plants, despite of separation in 2011 in to two countries still rich with valuable medicinal plants [2]. The medicinal and Aromatic Plants Research Institute (MAPRI) of the National Centre for Research (NCR) is playing and doing very great efforts for determination of therapeutic properties, studying medicinal and aromatic plants in Sudan. with this sole history and vast diversity of climate and flora, traditional medicine together with use of medicinal plants became an important part of the cultural heritage of Sudan [3-5].

Plant is an important source of medicine and plays a key role in world health [6]. Medicinal herbs or plants have been known to be a vital potential source of therapeutics or curative aids. This includes the use of medicinal plants not only for the treatment of diseases but also as potential material for maintaining good health and conditions. majority of the used drugs contain plant extracts. Some contain active ingredients (bioactive components or substances) obtained from plants. Through recent researches, plant-derived drugs were discovered from the study of curative, therapeutic, traditional cures and most especially the folk knowledge of local people and some of these claims and believe of people are irreplaceable despite the recent advancement in science and technology.

\section{The Role of Medicinal Plants in Traditional Healing}

The pharmacological treatment of disease began long ago with the use of herbs. Methods of folk healing all over the world commonly used herbs as part of their tradition, It is also a role of the traditionally-held belief that the synergistic mixture of several active principles in some herbal preparations is responsible for their beneficial effects [7]. Methods of traditional healing throughout the world usually used herbs as part of their tradition. The introduction of plant derived drugs in recent medicine has been linked to the uses of plant derived materials as an indigenous cure in traditional system of medicine [8]. Some of the plants have been found to possess significant antibacterial, antifungal, anticancer, antidiuretic, anti-inflammatory and anti-diabetic properties [9-12]. Some other uses of herbal medicines are in venom neutralization by lupeol acetate isolated from the root extract of Hemidesmus indicus [13] treatment of hypertension and lowering of blood sugar by serpentine isolated from the root of Rauwolfia serpentine, treatment of Hodgkin's, choriocarcinoma, non-Hodgkin lymphomas, leukemia in children, testicular and neck cancer from vinblastine isolated from the Catharanthus rosesus, [14] treatment of acute lymphoblastic leukemia in childhood advanced stages of Hodgkin's, lymophosarcoma, cervical and breast cancer amongst others. also plant derived drugs are used to treat mental illness, skin diseases, tuberculosis, diabetes, jaundice, hypertension and cancer.

\section{Traditional Uses of Some Plants}

Fabaceae is the third largest family of flowering plants with more than 18,000 described species including herbs, shrubs, trees and vines distributed throughout the world, especially in tropics rain forest and widespread in Sudan [15]. The Cajanus, Cajana, Family: Fabacea, Genus: Cajanus, Species: Cajan,flavu, Synonyms: Cajanus bicolor, Cajanus flavus. Seeds of Cajanus Cajan are reported to contain (per 100g) 345calories, $9.9 \%$ moisture,19.5g protein,1.3g fat,65.5g carbohydrate,1.3g fiber,3.8g ash,161mgCa, 285mgP, $15 \mathrm{mgFe}, 55 \mathrm{mgb}$-carotene equivalent, $0.72 \mathrm{mg}$ thiamine, $0.14 \mathrm{mg}$ riboflavin and $2.9 \mathrm{mg}$ niacin. Pigeon pea is a perennial tropical crop primarily grown in Asia and Africa, and its seeds are consumed as a very rich source of protein and carbohydrates both in fresh and dried forms. It has been used as a vital part of the folk and traditional medicine in India, China, and South America to prevent and treat various human diseases. Cajanus cajanis a perennial crop of subtropical and tropical regions, originated in the northern region of Indian sub-continent. It is also known as red gram, Congo Pea and no-eye pea which belongs to the family of Leguminosae [16].

The slave trade was a source of taking it to Africa and South America. It is cultivated in 22 countries worldwide (FAO,2008), but only a few countries with major productions. India, Myanmar, and Nepal are the foremost producers in Asia with India leading in the worldwide production of 2,584,007 tons as of 2014 (FAO, 2015). Kenya, Malawi, Uganda, Mozambique, and Tanzania are the primary producers of pigeon pea in Africa. Some South American countries like Brazil and the Caribbean islands also have equitable areas for its production. Average of production share from 2000 to 2015 in these three continents is, Asia 84.5\%, Africa $13.4 \%$, and Americas $2 \%$ (FAO, 2015). In the US, researchers at the University of Hawaii were among the earliest promoters in the state with a long tradition of cultivation [17]. Pigeon pea is an essential component of many people's diet in Asia, Africa and South America [18] It has been used to a attain the requirements of food, forage, feed, and therapeutics. Conventional consumption of seed is as a green vegetable and dry pulse, but young green pods, shoots, and leaves are also edible. Bioactive components in pulse seeds are getting increased attention in recent years.

\section{Physiological Activities of Pigeon Pea Seeds}

Antihyperglycemic \& Lipid Peroxidation: The indirect effect of total phenolics with increased antioxidant activity leading to the inhibitory potential of carbohydrate digesting enzymes and a positive correlation between consumption of germinated pigeon pea and controlling hyperglycemia. Reduction in lipid peroxidation and reduced fasting blood glucose level in diabetic rats [19]. The anti-hyperglycemic activity was found after administration of a single dose of unroasted seeds (60\% and $80 \%)$ and administration to normal as well as alloxanized mice, significant reduction in the glucose level in the blood after 1-2 hours and significant increase at 3hours [20]. 
Antioxidant Potential of Biological Pigeon: Pea proteins from seeds: Proteins isolated from pigeon pea seeds posed antioxidative effects on H2O2-induced cellular damage [21].

Anti-Inflammatory Activity: Investigational study on the effect of $50 \%$ ethanol extracts of pigeon pea, as well as its main component, cyanidin-3-monoglucoside, an anthocyanin, on DNA damage, the activity of antioxidant enzymes, and free radical scavenging capacity in hydrogen peroxide (H2O2)- treated RAW264.7 macrophages. 50\% ethanol extracts of pigeon pea and cyanidin-3-monoglucoside suppressed the production of inflammatory cytokines, including TNF- $\alpha$, IL-1 $\beta$, and IL-6, in these macrophages [22]. Also Cajaninstilbene acid (CSA) only found in pigeon pea and extracted from its leaves along with its synthesized derivatives revealed strong inhibition activity on the release of nitric oxide(NO) and inflammatory factor TNF- $\alpha$ and IL-6 in lipopolysaccharides (LPS)-stimulated mice macrophages [23].

Anti-Sickling Activity: Anti-sickling experiments depend on the estimation of free phenylalanine in the methanol (watersoluble) extract of the white variety seeds. The presence of phenylalanine amino acid alone could account for about $70 \%$ of the antisickling potency of Cajanus cajan seed extract [24].

Anti-Hypertensive Activity: Water extracts of pigeon pea (100 mg/kg body weight) and water extracts of B. subtilis-fermented pigeon pea (100mg/kg body weight) significantly improved systolic blood pressure $(21 \mathrm{mmHg}$ ) and diastolic blood pressure $(30 \mathrm{mmHg})$ in spontaneously hypertensive rats [25].

Anti-Dyslipidemic Activity: The anti dyslipidemic activity of pigeon pea was evaluated by high-fat diet (HFD) hamsters model, in which the level of high-density lipoprotein cholesterol (HDL-C), low-density lipoprotein-cholesterol (LDL-C), total cholesterol (TC), and total triglyceride (TG) were examined. Statistical results showed pigeon pea significantly elevated hepatic carnitine palmitoyltransferase-1 (CPT-1), LDL receptor, and cholesterol $7 \alpha$ - hydroxylase (also known as cytochrome P450 7A1, CYP7A1) expression to attenuate dyslipidemia in HFD-fed hamsters and markedly increased antioxidant enzymes in the liver of HFDinduced hamsters [26].

Antioxidant Potentials and Anti Hyperglycemic Activity: Methanolic extracts of seed husks were found to be the rich source of polyphenols and protein and possessed potent free radicals scavenging, antioxidant activities in vitro. Mitigated starch-induced postprandial glycaemic excursions and reduced glycaemic load in rats similar to the standard drug acarbose [27].

\section{Methods}

Study design and population: An experimental randomised controlled trial study was conducted at Khartoum State in Medical and Aromatic Plants Research Institute (MARPI) , 24 healthy Wistar Albino rats with both sex and age(6weeks) and weighing between (75-130) they were feed with standard laboratory chow and water.

\section{Sample Collection and Processing}

24 blood samples collected in EDTA container every week from the ocular vein of the eye.in weeks $(0,1,2$ and 3$)$.

\section{Ethical Statement}

Ethical approval was obtained from the department of Haematology and Immunohaematology, faculty of medical laboratory science, Omdurman Islamic University Ethics Committee and approval from Medicinal Aromatic plants Research Institute (MAPRI) and the National Centre for Research (NCR),Khartoum, Sudan. also was taken to conduct the laboratory work.

\section{Ethanolic extraction of Cajanus Cajan Seeds}

The Cajanus Cajan fresh seeds crushed to powder, dried and prepared plants material $(400 \mathrm{~g})$ was suspended in 1 litre of $80 \%$ ethanol for ( $24 \mathrm{hr}$ ) this suspension was re suspended in an equal volume of $80 \%$ ethanol for (48hr) and filtrated again the filtrates were pooled and the solvents were evaporate in a Rotavapor (Switzerland,BUCHI00I) or under reduced pressure [4].

\section{Haematological Methods}

Sample Collection: In EDTA blood sample these techniques were performed according to an automated haematology analyser (humacount plus gambh, Max-Planck-Ring 21.D-65205 Wiesbaden, Germany), automatic multipara-meter blood cell counter for in vitro diagnosis use in clinical laboratories. This study utilize the quantitative approach to measure blood parameter (RBCs, HB, PCV, MCV, MCH, MCHC, PLTs count and WBCs count) in haemorrhagic anaemic rat received Cajanus Cajan extraction. 24 healthy Wistar albino rat's male \& females with ages (6weeks) and weighing between $(75-130 \mathrm{~g})$, they were feed with standard laboratory chow and water. The rats were allocated in to 4 groups of 6 rats and labelled A, B, C, D, the averages of weight of rats for all groups were apparently the same:

Group A: control anaemic continued to be fed the normal diet and served as control.

Group B: gave $200 \mathrm{mg} / \mathrm{kg} /$ day of extract orally.

Group C: gave $400 \mathrm{mg} / \mathrm{kg} /$ day of extraction orally.

Group D: mg/ kg/ day of extraction orally.

The doses are given to rats according to weight the follow equation

Dose 1000

$\mathrm{X}$ B.W

B. $\mathrm{W}^{*}$ Dose $=\mathrm{X} 1000$

$30 \%$ of the blood is collected from the rat to become anaemic by the equation of bleeding as follow:

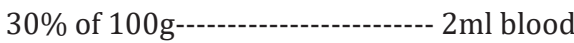


B.W $-\mathrm{X}$

Bleeding $=$ body weight $* 2 \mathrm{ml} / 100 \mathrm{r}$.

\section{Procedures}

Blood sample were collected from each group four times in week zero immediately after the bleeds, then after the first, second and third weeks. examined for determination of haemoglobin concentration, red blood cell count, total white blood cells count, packed cell volume, mean corpuscular volume, mean corpuscular haemoglobin, and mean corpuscular haemoglobin concentration.

\section{Statistical Analysis}

Statistical analysis was performed using package for social science (SPSS), version 20(IBM, corporation, New York, UAS). and excel and presented in table, figures

\section{Results}

Demographic information: 24 male Wistar albino rats (six weeks old) were house within the premises of the medicinal and aromatic plants research institute, which administered with daily doss for 3week. Examined for determination of haemoglobin concentration, Red blood cell count, Total white blood cells count, Platelets count, packed cell volume, mean corpuscular volume, mean corpuscular haemoglobin and mean corpuscular haemoglobin concentration.

\section{Haematological Results}

There are significant $(\mathrm{p}<0.05)$ progressive blood parameter (HB, PCV, RBCs) related to the number of doses. After 3 weeks the result analyzed statistically by SPSS and Excel and expressed as follow: Table 4-1 showed the Mean, Mode and SD for (RBCs, HB,),Table 4-2 showed Mean, Mode and SD for(PCV,PLT) (Table 1). Table 4-3 showed showed Mean, Mode, SD of (MCV, MCH).Table 4-4 showed Mean, Mode, SD of MCHC (Table 2). Table 4-5 showed P values, 4-6 showed Increasing rate for different blood parameter (HB,PCV,RBCs) in three weeks and Table 4-7 showed the correlation between (W0\&W1,W0 \&W2,W0\&W3) (Table 3), Table Figure (4-1) showed the progression of HB in four weeks (Figure 1), Figure (42) showed the progression of RBCs in four weeks (Figure 2), Figure (4-3) showed the progression of ,PCV in four weeks, Figure (4-4) showed the progression of PLT in three weeks (Figure 3).

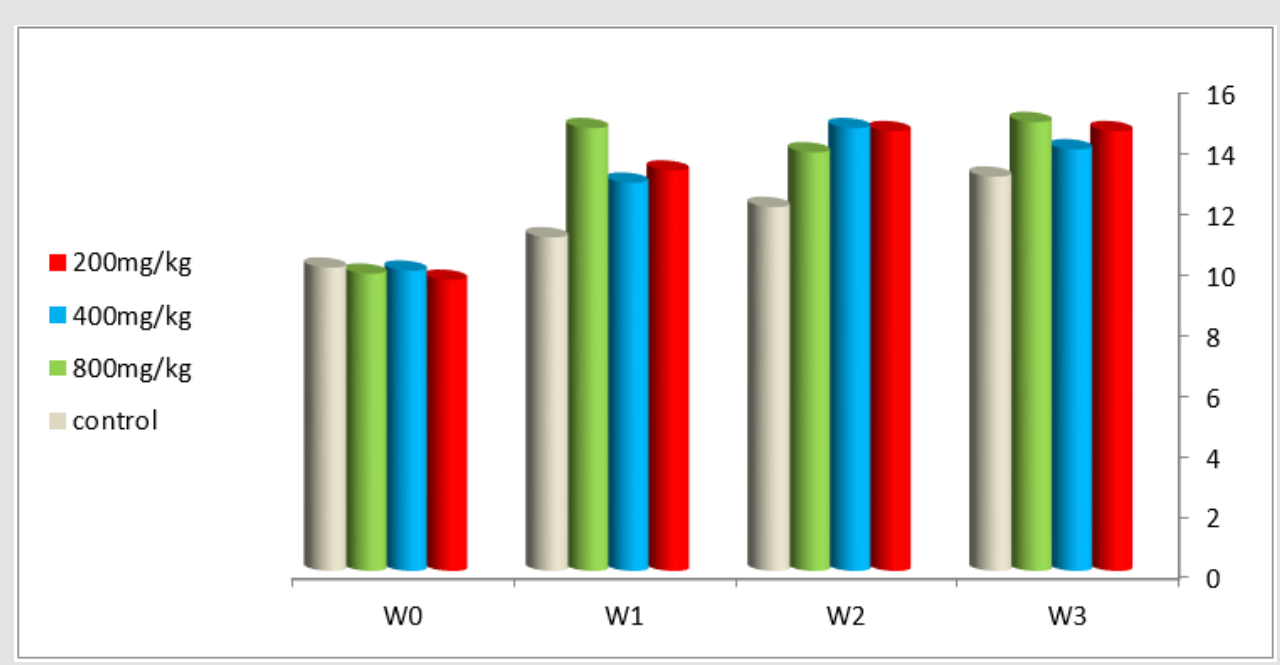

Figure 1: Effect of Cajanus Cajana on HB in hemorrhagic rats (HB).

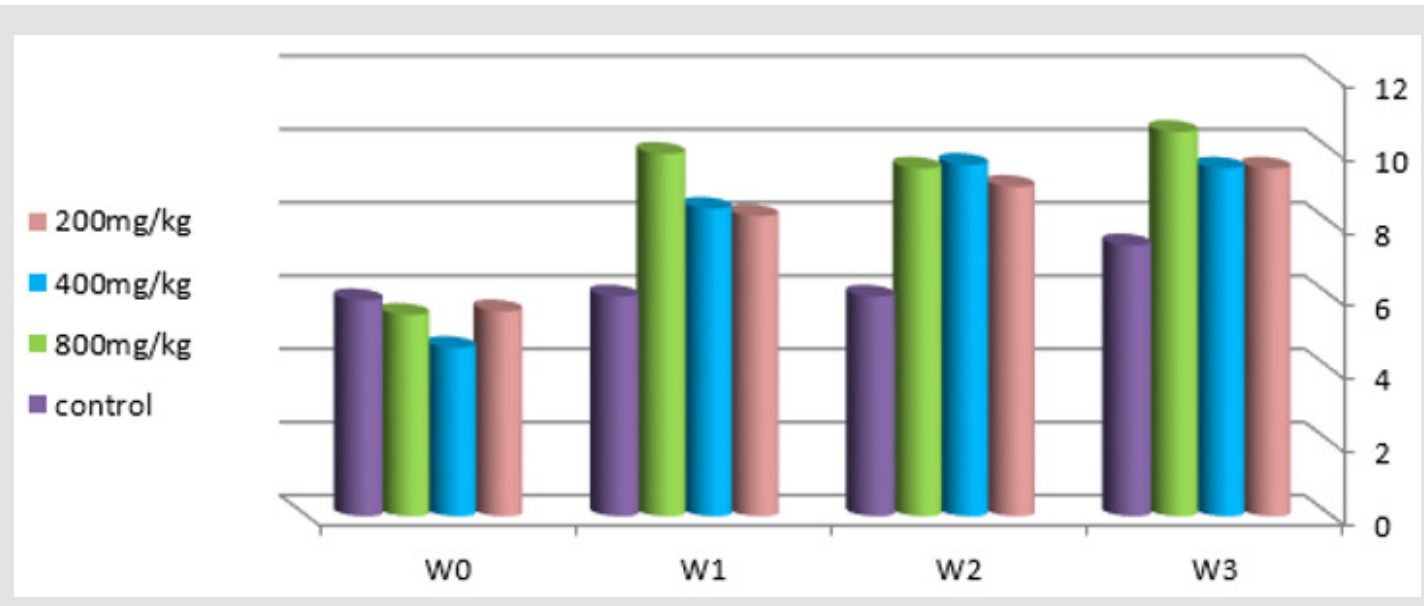

Figure 2: Effect of Cajanus Cajana on RBCs in hemorrhagic anemic rats (PCV). 


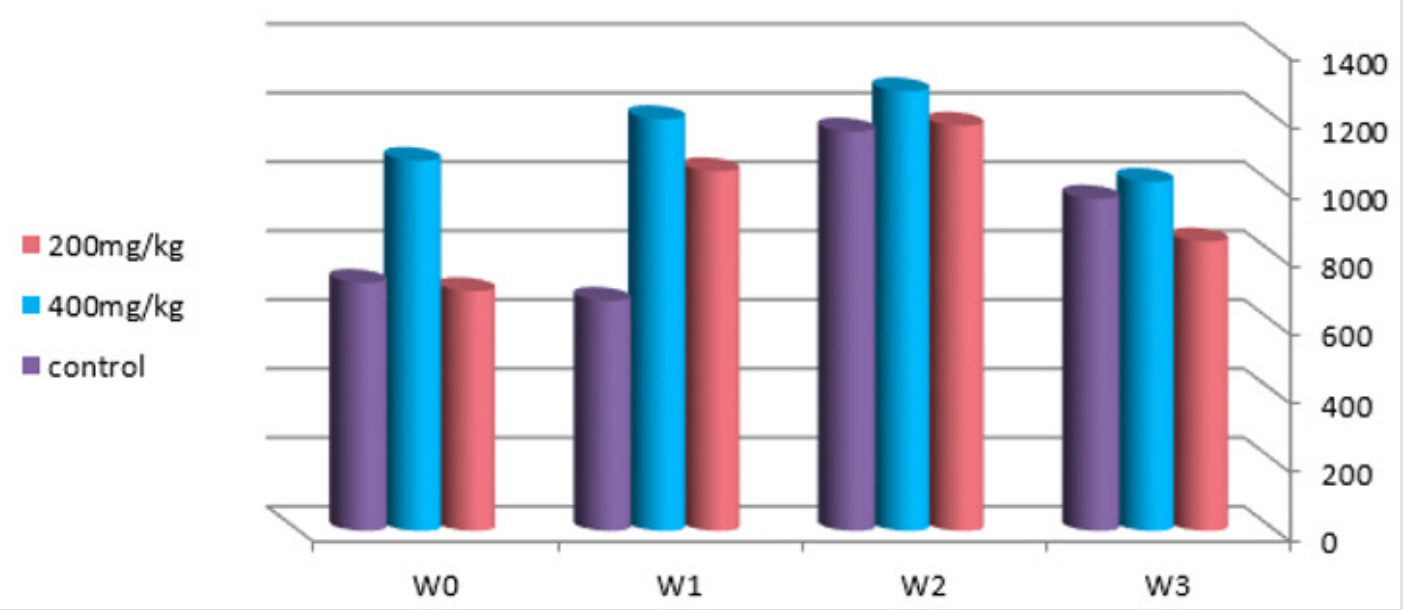

Figure 3: Effect of Cajanus Cajana on PLTs in hemorrhagic anemia (platelets).

Table 1: Mean, Mode, SD of Hemoglobin, Red Blood Cells count, Packed Cell Volume and Platelets count.

\begin{tabular}{|c|c|c|c|c|c|c|c|c|c|c|c|c|}
\hline \multirow{2}{*}{ CONTROL } & \multicolumn{3}{|c|}{ HB } & \multicolumn{3}{|c|}{ RBCS } & \multicolumn{3}{|c|}{ PCV } & \multicolumn{3}{|c|}{ PLT } \\
\hline & Mean & Mode & $\mathrm{SD}$ & Mean & Mode & SD & Mean & Mode & SD & Mean & Mode & SD \\
\hline Wo & 10.6 & 10 & 1.5 & 5.97 & - & 1.2 & 35.28 & 33 & 5 & 682 & - & 152 \\
\hline W1 & 11.88 & 11 & 0.6 & 6.03 & - & 0.28 & 35.28 & 55 & 5.5 & 1088 & - & 300 \\
\hline W2 & 12 & 15 & 0.21 & 6.03 & - & 0.28 & 36.14 & - & 0.55 & 1049 & - & 422 \\
\hline W3 & 13.72 & 14.7 & 5 & 7.44 & 9.6 & 1.55 & 36.14 & - & 1.55 & 964 & - & 162 \\
\hline \multicolumn{13}{|c|}{$200 \mathrm{mg} / \mathrm{kg}$} \\
\hline Wo & 9.6 & - & 0.3 & 5.6 & 5.6 & 0.4 & 33.3 & 35 & 2 & 696 & - & 89 \\
\hline W1 & 13.2 & 13.4 & 1.1 & 8.2 & - & 1.1 & 51.4 & - & 7 & 1044 & - & 320 \\
\hline W2 & 14.5 & - & 2.5 & 9 & - & 0.05 & 54.8 & - & 54 & 1176 & - & 243 \\
\hline W3 & 14.5 & - & 1.2 & 9.5 & - & 0.6 & 61.8 & - & 22 & 840 & - & 1678 \\
\hline \multicolumn{13}{|c|}{$400 \mathrm{mg} / \mathrm{kg}$} \\
\hline W0 & 9.9 & 10 & 0.5 & 4.6 & - & 2 & 33.4 & 34 & 17 & 1074 & - & 195 \\
\hline W1 & 12.8 & - & 1,3 & 8.4 & - & 0.8 & 53.4 & - & 56 & 1195 & - & 603 \\
\hline W2 & 14.6 & - & & 9.6 & - & 2.2 & 57.5 & - & 11 & 1276 & - & 235 \\
\hline W3 & 13.9 & 13.3 & & 9.5 & - & 0.6 & 58.3 & - & 26 & 1013 & - & 186 \\
\hline \multicolumn{13}{|c|}{$800 \mathrm{mg} / \mathrm{kg}$} \\
\hline wo & 9.8 & - & 0.8 & 5.5 & - & 0.5 & 32.6 & 35 & 24 & 910 & - & 476 \\
\hline W1 & 14.6 & - & 1.7 & 9.9 & - & 1.7 & 62 & - & 7.2 & 850.6 & - & 58 \\
\hline W2 & 13.8 & - & 2.2 & 9.5 & - & 1.6 & 57 & - & 10 & 1005 & - & 333 \\
\hline W3 & 14.8 & 14.5 & 0.5 & 10.5 & - & & 62.9 & - & 2 & 826 & - & 105 \\
\hline
\end{tabular}

Table 2: Mean, Mode, SD of Ref Blood Cells indices.

\begin{tabular}{|c|c|c|c|c|c|c|c|c|c|}
\hline \multirow{2}{*}{ CONTROL } & \multicolumn{3}{|c|}{ MCV } & \multicolumn{3}{|c|}{ MCH } & \multicolumn{3}{|c|}{ MCHC } \\
\hline & Mean & Mode & SD & Mean & Mode & SD & Mean & Mode & SD \\
\hline W0 & 59.24 & - & 1.7 & 17.82 & - & 0.7 & 30.52 & 24 & 2.1 \\
\hline W1 & 65.2 & - & 2.66 & 20.1 & - & 1.75 & 30.78 & - & 2.18 \\
\hline W2 & 60.02 & 58 & 2.04 & 19.9 & - & 0.78 & 33.14 & 26 & 0.21 \\
\hline W3 & 60.58 & 65 & 1.61 & 18.48 & - & 0.61 & 33.14 & - & 0.21 \\
\hline \multicolumn{10}{|c|}{$200 \mathrm{mg} / \mathrm{kg}$} \\
\hline W0 & 61.5 & 62 & 0.9 & 15.1 & 14.5 & 0.6 & 25 & 24.7 & 0.7 \\
\hline W1 & 63 & 62 & 1.5 & 15.7 & 14.7 & 1.7 & 25 & - & 1.5 \\
\hline W2 & 61 & 62 & 1.4 & 15.2 & - & 0.9 & 26.4 & - & 1.4 \\
\hline
\end{tabular}




\begin{tabular}{|c|c|c|c|c|c|c|c|c|c|}
\hline W3 & 62 & 61 & 1.4 & 15.21 & - & & 24.5 & - & 1.7 \\
\hline \multicolumn{10}{|c|}{$400 \mathrm{mg} / \mathrm{kg}$} \\
\hline W0 & 64 & 59 & 4.2 & 16.3 & - & 1.6 & 25.4 & 25 & 0.9 \\
\hline W1 & 63.5 & 63 & 3.3 & 15.2 & - & 1.2 & 23 & - & 1.2 \\
\hline W2 & 60.1 & 60 & 2.3 & 16.4 & - & 3.9 & 27.1 & 24.8 & 5.6 \\
\hline W3 & 61.6 & 62 & 2.2 & 14.6 & - & 0.4 & 23.8 & 23.7 & 0.2 \\
\hline \multicolumn{10}{|c|}{$800 \mathrm{mg} / \mathrm{kg}$} \\
\hline W0 & 62.2 & 60 & 2.6 & 14.8 & - & 5 & 24.8 & - & 1.7 \\
\hline W1 & 62 & 61 & 3.7 & 14 & - & 0.7 & 23.5 & - & 1.2 \\
\hline W2 & 60 & 58 & 2.9 & 14.5 & - & 0.9 & 24.2 & - & 0.7 \\
\hline W3 & 60 & - & 3.1 & 14.1 & - & 0.8 & 23.5 & - & 0.3 \\
\hline
\end{tabular}

Table 3: Mean, Mode, SD of Ref Blood Cells indices.

\begin{tabular}{|c|c|c|c|}
\hline $200 \mathrm{mg} / \mathrm{Kg}$ & W0\&W1 & W0\&W2 & W0\&W3 \\
\hline HB & 0.005 & 0.023 & 0.007 \\
\hline RBCS & 5.03 & 0.005 & 0.003 \\
\hline PCV & 0.01 & 0.005 & 0.00005 \\
\hline PLT & 0.15 & 0.04 & 0.2 \\
\hline \multicolumn{4}{|c|}{$400 \mathrm{mg} / \mathrm{Kg}$} \\
\hline HB & 0.003 & 0.006 & 0.00004 \\
\hline RBCS & 0.009 & 0.0006 & 0.0009 \\
\hline PCV & 0.0004 & 0.004 & 0.00001 \\
\hline PLT & 0.7 & 0.08 & 0.3 \\
\hline \multicolumn{4}{|c|}{$800 \mathrm{mg} / \mathrm{Kg}$} \\
\hline HB & 0.001 & 0.03 & 0.0002 \\
\hline RBCS & 0.0004 & 0.004 & 0.00005 \\
\hline PCV & 0.0005 & 0.01 & 0.00003 \\
\hline PLT & 0.8 & 0.7 & 0.7 \\
\hline
\end{tabular}

\section{Discussion}

The result of the presentstudy showed that the body mechanism of the bled rat responded to about blood loss by rapid generation of RBCS with in 3weeks and increase in HB, PCV by administration of ethanolic extract of cajanus cajan in significant result $(\mathrm{p}<0.05)$. Administration of alcoholic extraction of cajanus cajan increase the recovery of treated rats from effect of bleeding. The lowest administration dose $200 \mathrm{mg} / \mathrm{kg}$ reduced the recovery time of most blood parameters from about 3weeks in the bled control to 1 week. in addition, the extent of recovery was dose related with highest dose of $800 \mathrm{mg} / \mathrm{kg}$ effecting the highest change. The observed elevation of mean cell volume in bled rats by week1 is indicative of anaemia due to acute blood loss.

\section{Conclusion}

Pigeon pea is a perennial tropical crop primarily grown in Asia and Africa, and its seeds are consumed as a rich source of protein and carbohydrates both in fresh and dried forms. This crop has been successfully grown in some southeastern states but still considered as a novel pulse here in the US. Majority of the work focused on its non-consumable parts like leaves, stems, and roots. In this study we used the seeds extraction of Cajanus Cajan to work on it. Literature studies indicate that pigeon pea has the potential to prevent and treat many human diseases such as bronchitis, pneumonia, measles, hepatitis, yellow fever, ulcers, diabetes, and certain forms of cancer. Along with protein and fiber, it has a decent number of healthpromoting phytochemicals. Important phytochemicals found in pigeon pea seeds are phenolic acids, flavonoids, tannins, saponins, and phytic acid. These minor components predominately exhibit and are capable of antioxidant, antidiabetic, and anti-inflammatory activities. Seeds are the edible and non-perishable part of this crop with the feasibility of addition in food products. Exploring the nonstarch polysaccharide fractions and functional properties of the pigeon pea flour can make it a gluten-free substitute for cereals. The overall results of this study lend support to the folkloric use of ethanol seed extract of Cajanus Cajan in treatment of haemorrhagic anaemia.

\section{Acknowledgement}

The authors would like to acknowledge the study participants and team in Sudan and Algeria. The author appreciates the effort of the staff members of Medicinal and Aromatic Plants Research 
Institute (MAPRI),National Centre For Research(NCR),Khartoum, Sudan, for their permission and grate helps to carry out this work. Particular thank to Dr. Reem Hassan, Dr. Alkhatim.

\section{Author's Contributions}

KMKEH, NNB, SHM, TEMA, WEA, NNB and WMHA conceived and designed the study. KMKEH, NNB ,MEHO and AAIA prepared the manuscript. KMKEH, SHM, TEMA, WEM and WMHA performed the sample collection. KMKEH, SHM, TEMA, EEA and WMHA performed the laboratory work. KMKEH, SHM, TEMA, WEA and WMHA analyzed the data. KMKEH, NNB, AAIA, and MEHO helped in study implementation. All authors read and approved the final manuscript.

\section{Ethics approval and Consent to Participate}

Approval was obtained from Medicinal and Aromatic Plant Research Institute (MAPRI), National Centre For Research (NCR), Khartoum, Sudan to conduct the laboratory work. The study and its procedures were approved by Research Ethics Committee (REC), Omdurman Ahlia University-Faculty of Medicine.

\section{References}

1. Martin AS, Steininger CA, Koepke JA (1998) Clinical haematology principle, procedures, correlation ( $2^{\text {nd }}$ Edn.), Wolters Kluwer, Netherlands.

2. Tarig O Khider (2018) A Look at Some Medicinal Plants from Sudan-Mini Review. Journal of advanced pharmacy research 2(4): 238-246.

3. Elkhalifa MY (2003) Women and income generating activities and conservation of natural resources: Medicinal, culinary and aromatic plants in the Sudan. A document of the FAO Regional Office for the Near East. FAO.

4. El Ghazali G, Abdalla W, Khalid H, Khalafalla M, Hamad A (2003) Medicinal plants of Sudan part V, medicinal plants of Ingasana area. Ministry of Science and Technology National Centre for Research Medicinal and Aromatic Plants Research Institute.

5. El badwi SM, Hassan SM, Gameel A (2014) Medicinal plants in Sudan: role in animal and human health, productivity and poverty Alleviation. Flora of the Sudan Conference: the $5^{\text {th }}$ Annual Conference of the Graduate College, University of Khartoum 24-27 February Khartoum Sudan, At University of Khartoum Sudan.

6. Sandberg F, Corrigan D (2001) Natural Remedies. Their Origins and Uses. Taylor \& Francis, Abingdon, UK.

7. Taiz L, Zeiger E (1991) Plant Physiology (3 ${ }^{\text {rd }}$ Edn.)., The Benjamin Publishing Company, California, USA

8. Igoli JO, Ogaji OG, Igoli NP, Tor Anyiin TA (2003) Traditional Medicine Practice amongst the Igede People of Nigeria. Part II. Afr J Trad CAM 10(4): 1-10.

9. Timothy SY, Lamu FW, Rhoda AS (2012) Acute toxicity, Phytochemistry and antibacterial activity of aqueous and ethanolic leaf extracts of Cassia alata L. Int Res J Pharma 3(6): 73-76.

10. Oladeji SO (2016) Thin-layer chromatographic analysis of flavonoids and total phenolics in methanolic and ethanolic extracts of Senna alata (L.) Roxb. (Fabales: Fabaceae). Brazil J Biol Sci 3(5): 221-225.

11. Adelowo FE, Oladeji SO (2016) Spectrophotometric analysis of phenolic compounds in Senna alata. Am J Adv Sci Res 3(2): 246-253.

12. Midawa SM (2010) Cutaneous wound healing activity of the ethanolic extracts of the leaf of Senna alata L. (Fabaceae). J Biol Sci 2: 63-68.

13. Chatterjee IC, Gomesan A (2006) Plant phenolic compounds. Britain J Ethnopharmacol 6: 38-43.

14. Farnsworth NR, Bunyapraphatsara N (1992) Thai Medicinal Plant: Recommended for Primary Health Care System. Prachachon Company, Bangkok, Thailand.

15. El Amin, Hamaza M (1990) Food and Agriculture Organization (FA0), Tree and Shrubs of the Sudan, Ithaca press Exeter. pp. 1-484.

16. Wu N, Fu K, Fu YJ, Zu YG, Chang FR, et al. (2009) Antioxidant Activities of Extracts and Main Components of Pigeonpea [Cajanus cajan (L.) Millsp.] leaves. Molecules 14(3): 1032-1043.

17. Valenzuela HR, Smith J (2002) CTAHR Sustainable Agriculture Green Manure Crops Series: Pigeonpea Univ Hawaii Coop Ext Serv SA-GM-8.

18. Martínez Villaluengaa C, Torresb A, Friasa J, Vidal Valverde C (2010) Semolina supplementation with processed lupin and pigeon pea flours improveprotein quality of pasta Volume. LWT - Food Science and Technology 43(4): 617-622

19. Uchegbu NN, Ishiwu CN (2016) Germinated Pigeon Pea (Cajanus cajan): a novel diet for lowering oxidative stress and hyperglycemia. Food Sci Nutr 4(5): 772-777.

20. Amalraj T, Ignacimuthu S (1998) Hypoglycemic activity of Cajanus cajan (seeds) in mice. Indian J Exp Biol 36(10): 1032-1033.

21. Muangman T, Leelamanit W, Klungsupaya P (2011) Crude proteins from pigeon pea (Cajanus cajan (L.) Millsp) possess potent SOD-like activity and genoprotective effect against $\mathrm{H} 2 \mathrm{O} 2$ in TK6 cells. Journal of medicinal plant research 5(32): 6977-6986.

22. Lai YS, Hsu WH, Huang JJ, Wu SC (2012) Antioxidant and antiinflammatory effects of pigeon pea (Cajanus cajan L.) extracts on hydrogen peroxide and lipopolysaccharide treated RAW264.7 macrophages. Food Funct 3(12): 1294-1301.

23. Huang MY, Lin J, Lu K, Xu HG, Geng ZZ, et al. (2016) Anti-Inflammatory Effects of Cajaninstilbene Acid and Its Derivatives. J Agric Food Chem 64(14): 2893-900.

24. Ekeke GI, Shode EO (1990) Phenylalanine, the predominant anti-sickling agent in Cajanus cajan seed extract. Plant Media 56(1): 41-43.

25. Lee BH, Lai YS, Wu SC (2015) Antioxidation, angiotensin converting enzyme inhibition activity, nattokinase, and antihypertension of Bacillus subtilis (natto)-fermented pigeon pea. J Food Drug Anal 23(4): 750-757.

26. Dai FJ, Hsu WH, Huang JJ, Wu SC (2013) Effect of pigeon pea (Cajanus cajan L.) on high-fat diet-induced hypercholesterolemia in hamsters. Food and Chemical Toxicology 53: 384-391.

27. Ashok KT, Bacha A, Katragadda SB, Domati AK, Amtul Z et al. (2013) 
ISSN: 2574-1241

DOI: 10.26717/BJSTR.2020.25.004220

Khalid Mohamed Khalid Elhussain. Biomed J Sci \& Tech Res

(c) (P) This work is licensed under Creative BY Commons Attribution 4.0 License

Submission Link: https://biomedres.us/submit-manuscript.php

$\begin{array}{ll}\text { BIOMEDICAL } & \text { Assets of Publishing with us } \\ \text { RESEARCHES } & \text { - Global archiving of articles } \\ \text { - Immediate, unrestricted online access } & \text { - Rigorous Peer Review Process } \\ & \text { - Authors Retain Copyrights } \\ & \end{array}$

